\title{
Catalytic Effects of Barium Carbonate on the Anodic Performance of Solid Oxide Fuel Cells
}

\author{
Sung-Eun Yoon, Jae-Yeong Ahn, and Jong-Sung Park ${ }^{\dagger}$ \\ Department of Material Science and Engineering, Myongii University, Yongin 17058, Korea \\ (Received July 30, 2015; Revised September 10, 2015; Accepted September 11, 2015)
}

\begin{abstract}
To develop ceramic composite anodes of solid oxide fuel cells without metal catalysts, a small amount of barium carbonate was added to an $\left(\mathrm{La}_{0.8} \mathrm{Sr}_{0.2}\right)\left(\mathrm{Cr}_{0.5} \mathrm{Mn}_{0.5}\right) \mathrm{O}_{3}$ (LSCM) - YSZ ceramic composite anode and its catalytic effects on the electrode performance were investigated. A barium precursor solution with citric acid was used to synthesize the barium carbonate during ignition, while a barium precursor solution without citric acid was used to create hydrated barium hydroxide. The addition of barium carbonate to the ceramic composite anode caused stable fuel cell performance at $1073 \mathrm{~K}$; this performance was higher than that of a fuel cell with $\mathrm{CeO}_{2}$ catalyst; however, the addition of hydrated barium hydroxide to the ceramic composite anode caused poor stability of the fuel cell performance.
\end{abstract}

Key words : Ceramic catalysts, Ceramic composite anode, Barium carbonate, Solid oxide fuel cells

\section{Introduction}

F uel cells are electrochemical energy conversion devices with high energy conversion efficiency and fuel flexibility. Because solid oxide fuel cells (SOFC) usually perform at temperatures higher than $873 \mathrm{~K}$, hydro-carbon fuels, such as methane, can be used without subjecting the fuels to a reformation process; decent performance can also be obtained without using noble metal catalysts in the electrodes. ${ }^{1)}$

Due to the high operating temperature of SOFCs, ceramic catalysts have been adopted in the cathodes and anodes of these devices, while PEMFCs, which operate at low temperatures, require noble metal catalysts in their cathodes and anodes. ${ }^{2,3)}$ For the cathodes of SOFCs, many different types of oxides, such as $\left(\mathrm{La}_{0.8} \mathrm{Sr}_{0.2}\right) \mathrm{MnO}_{3},\left(\mathrm{La}_{0.8} \mathrm{Sr}_{0.2}\right) \mathrm{CoO}_{3}$, $\left(\mathrm{La}_{0.8} \mathrm{Sr}_{0.2}\right) \mathrm{FeO}_{3}$ (LSF), $\left(\mathrm{Ba}_{0.5} \mathrm{Sr}_{0.5}\right)\left(\mathrm{Co}_{0.8} \mathrm{Fe}_{0.2}\right) \mathrm{O}_{3 . \delta}$, and $\mathrm{SmBa}_{0.5}$ $\mathrm{Sr}_{0.5} \mathrm{Co}_{2} \mathrm{O}_{6-\delta}$, have been actively studied; most of these ceramic electrodes have mixed ionic electronic conductivity (MIEC) and good catalytic activity for the oxygen reduction reaction in air atmosphere. ${ }^{3)}$ Ceramic composite electrodes composed of MIEC ceramic and yttria-stabilized zirconia (YSZ) show high cathodic performance; indeed, catalytically active ceramics have been infiltrated into ceramic composite electrodes to obtain both long-term stability and high catalytic activity. ${ }^{4)}$

On the other hand, ceramic catalysts for anodes have been less studied than those for cathodes. The Nickel-YSZ cermet

${ }^{\dagger}$ Corresponding author : Jong-Sung Park E-mail : jspark.phd@mju.ac.kr, jspark.phd@gmail.com

Tel : +82-31-330-6467 Fax : +82-31-330-6469 has been widely used because nickel has high electrical conductivity and good catalytic activity for the hydrogen oxidation reaction; however, nickel has problems of carbon coaking and sulfur poisoning in hydrocarbon fuels; it also coarsens at high temperature, which causes degradation in performance. ${ }^{5}$ Therefore, to replace this cermet with a ceramic composite anode, electrically conductive ceramics in reduced atmosphere and ceramic catalysts for hydrogen oxidation reactions have been studied recently. ${ }^{2)}$

Several ceramics, such as $\left(\mathrm{La}_{0.8} \mathrm{Sr}_{0.2}\right)\left(\mathrm{Cr}_{0.5} \mathrm{Mn}_{0.5}\right) \mathrm{O}_{3}$ (LSCM) and (La, $\mathrm{Sr}) \mathrm{VO}_{3}$, have been studied as electrically conductive ceramics in reducing atmospheres. ${ }^{6-8)}$ It has been reported that LSCM has a higher catalytic activity than that of LSV, although the electrical conductivity of LSCM is lower than that of $\mathrm{LSV} .{ }^{7,8)} \mathrm{CeO}_{2}$ or modified $\mathrm{CeO}_{2}$ has been the most widely used material in ceramic composite anodes as a catalyst for the HOR. ${ }^{9)}$

Recently, it was reported that $\mathrm{BaO}$ nano particles dispersed on Ni/YSZ cermet can inhibit carbon coaking by water mediated carbon removal; also, the addition of $\mathrm{CaO}$ to $\mathrm{Ni} / \mathrm{CeO}_{2}-\mathrm{Sm}_{2} \mathrm{O}_{3}(\mathrm{Ni} / \mathrm{SDC})$ has been found to enhance the stability of fuel cell performance for direct methane fuel. ${ }^{10,11)}$ $\mathrm{BaCO}_{3}$ nano particles were tested in the LSF cathode as catalysts; they were found to enhance the cathode performance of LSF. ${ }^{12)}$ Therefore, in this work, barium carbonate or barium hydroxide were incorporated into a porous LSCM-YSZ ceramic composite anode; to investigate the catalytic activity of these materials in ceramic composite anodes, their electrode performances were compared with that of $\mathrm{CeO}_{2}$ catalysts in reducing atmosphere. 


\section{Experimental Procedure}

Electrolyte supported SOFCs were fabricated by casting tapes for the dense electrolyte and the porous electrode and infiltrating the active electrode components into a porous electrode scaffold. To make a porous/dense/porous three layered structure, two different types of tape were fabricated using the tape casting method. The tape for the dense YSZ layer was made from a slurry of organic solvents, such as xylene and alcohol; the tape for the porous YSZ layer was fabricated by adding graphite powder to the slurry as a pore former. A more detailed description of the formulating of the tape can be found in a previous work. ${ }^{7)}$ Tapes with graphite powder for the porous YSZ layers were laminated on both sides of the tape for a dense YSZ layer; these laminated tapes were sintered at $1773 \mathrm{~K}$ for $4 \mathrm{~h}$. After that, porous/dense/porous YSZ layered structures were obtained. The porosity of the porous layer was about $70 \%$; the thicknesses of the porous electrode layer and of the dense electrolyte layer were $40 \mu \mathrm{m}$ and $80 \mu \mathrm{m}$, respectively.

To make the LSF-YSZ cathode and the LSCM-YSZ anode composite electrode, LSF and LSCM precursor solutions were fabricated by dissolving the appropriate amounts of precursors, $\mathrm{La}\left(\mathrm{NO}_{3}\right)_{3} \cdot 6 \mathrm{H}_{2} \mathrm{O}\left(99.9 \%\right.$, Alfa Aesar), $\mathrm{Sr}\left(\mathrm{NO}_{3}\right)_{2}$ (99.9\%, Alfa Aesar), $\mathrm{Fe}\left(\mathrm{NO}_{3}\right)_{3} \cdot 9 \mathrm{H}_{2} \mathrm{O}$ (99.6\%, Alfa Aesar), $\mathrm{Cr}\left(\mathrm{NO}_{3}\right)_{3} \cdot 9 \mathrm{H}_{2} \mathrm{O}\left(99.3 \%\right.$, Alfa Aesar), $\mathrm{Mn}\left(\mathrm{NO}_{3}\right)_{2} \cdot \mathrm{H}_{2} \mathrm{O}(99.9 \%$, Alfa Aesar), and citric acid, in water. The exact compositions of LSF and LSCM were $\left(\mathrm{La}_{0.8} \mathrm{Sr}_{0.2}\right) \mathrm{FeO}_{3}$ and $\left(\mathrm{La}_{0.8}\right.$ $\left.\mathrm{Sr}_{0.2}\right)\left(\mathrm{Cr}_{0.5} \mathrm{Mn}_{0.5}\right) \mathrm{O}_{3}$, respectively; the number of moles of citric acid was equal to the number of moles of the cations in the aqueous solutions. The molar concentrations of LSF and LSCM were $0.8 \mathrm{M}$ and $0.7 \mathrm{M}$, respectively.

To make the LSCM-YSZ composite anode, the LSCM precursor solution was infiltrated several times into one of the porous YSZ scaffolds on the dense YSZ electrolyte until the loaded LSCM reached 30 vol\%. After each infiltration, the cell was fired at $973 \mathrm{~K}$ to burn out the organic species. After reaching the target vol\% of LSCM, the cell was calcined at $1223 \mathrm{~K}$ for $1 \mathrm{~h}$ to synthesize the perovskite single phase of LSCM. Then, to make the LSF-YSZ composite cathode, the 20 vol\% LSF was loaded into the porous scaffold on the other side of the dense electrolyte in the same way and calcined at $1123 \mathrm{~K}$ for $1 \mathrm{~h}$ to obtain a single phase of LSF.

The $\mathrm{CeO}_{2}$ catalyst was incorporated into the LSCM-YSZ composite anode by infiltrating the aqueous solution of $1 \mathrm{M}$ $\mathrm{Ce}\left(\mathrm{NO}_{3}\right)_{3}$ (Alfa Aesar, 99.5\%) with citric acid; aqueous solution of $0.25 \mathrm{M} \mathrm{Ba}\left(\mathrm{NO}_{3}\right)_{2}$ (Alfa Aesar, 99+\%) with or without citric acid was used to add barium carbonate and the barium hydroxide catalysts to the LSCM-YSZ composite anode. The number of infiltrations of the $\mathrm{Ce}\left(\mathrm{NO}_{3}\right)_{3}$ and $\mathrm{Ba}\left(\mathrm{NO}_{3}\right)_{2}$ precursor solutions were 1 and 4 , respectively, considering that the concentration of the $\mathrm{Ce}\left(\mathrm{NO}_{3}\right)_{3}$ precursor solution was four times larger than that of the $\mathrm{Ba}\left(\mathrm{NO}_{3}\right)_{2}$ precursor solution. After infiltrating the precursor solution of catalysts, the cells were fired at $673 \mathrm{~K}$ in air, $\mathrm{P}\left(\mathrm{O}_{2}\right)=0.21$, before painting the silver paste on the electrode as the current collector.
To measure the fuel cell performances, a ceramic adhesive (Ceramabond 552, Aremco) was used to mount the fabricated fuel cells on an alumina tube. Humidified $\left(3 \% \mathrm{H}_{2} \mathrm{O}\right)$ air and hydrogen were flowed into the cathode and the anode, respectively. The electrochemical impedance spectra (EIS) and the $V$-i polarization curve were measured using a potentiostat (Gamry Instruments) at $1073 \mathrm{~K}$. The EIS in the fuel cell mode were measured at a $-0.10 \mathrm{~V}$ bias voltage in the frequency range of $100 \mathrm{kHZ}$ to $0.01 \mathrm{~Hz}$ with $20 \mathrm{mV} \mathrm{AC}$ perturbation.

To investigate the crystal structure of the infiltrated barium precursor solution in the fuel cell operating conditions, aqueous solutions of the barium precursor with and without citric acid were dried on a hot plate and fired at $673 \mathrm{~K}$ in air. The obtained powders were treated in a humidified hydrogen atmosphere at $1073 \mathrm{~K}$ for $2 \mathrm{~h}$; these conditions were the same as the fuel cell operating conditions. Then, the crystal structures of the obtained powder were examined using Xray diffraction (XRD) analysis.

Half-cell testing of the LSF was also performed at $1073 \mathrm{~K}$ to identify the contribution of the cathode to the total impedance spectra. A symmetric LSF cell was fabricated by infiltrating the LSF precursor solution into the porous scaffold layers on both sides of the electrolyte layer. The EIS of the symmetric LSF cell were measured in air atmosphere at $1073 \mathrm{~K}$.

\section{Results and Discussion}

Figure 1 provides the XRD patterns of the barium-precursor solution (a) with and (b) without citric acid after treatment in the hydrogen atmosphere at $1073 \mathrm{~K}$ for $2 \mathrm{~h}$; also shown are the XRD peaks of $\mathrm{BaCO}_{3}$ (JCPDS 71-2394) and $\mathrm{Ba}(\mathrm{OH})_{2} \cdot \mathrm{H}_{2} \mathrm{O}$ (JCPDS 78-1831). The XRD pattern of the barium precursor solution with citric acid after treatment in

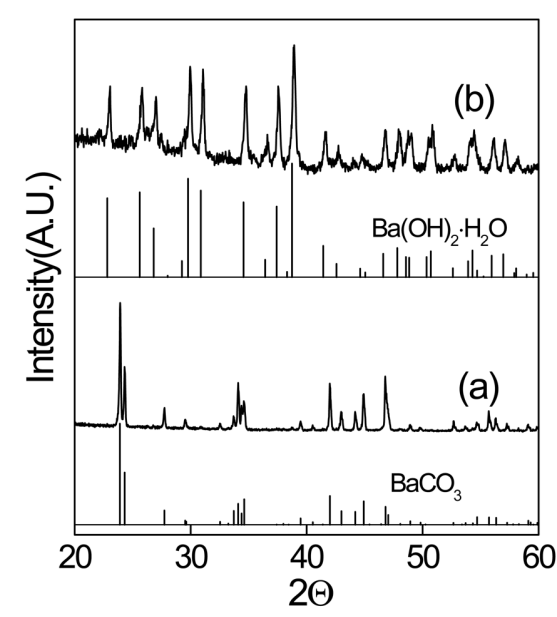

Fig. 1. XRD patterns of the barium-precursor solution (a) with and (b) without citric acid after treatment in hydrogen atmosphere at $1073 \mathrm{~K}$ for $2 \mathrm{~h}$, along with XRD peaks of $\mathrm{BaCO}_{3}$ (JCPDS 71-2394) and $\mathrm{Ba}(\mathrm{OH})_{2}$. $\mathrm{H}_{2} \mathrm{O}$ (JCPDS 78-1831). 
the hydrogen atmosphere at $1073 \mathrm{~K}$ was identical to that of the barium carbonate, $\mathrm{BaCO}_{3}$, while the pattern of the barium precursor solution without citric acid was identical to that of the mono hydrated barium hydroxide, $\mathrm{Ba}(\mathrm{OH})_{2} \cdot \mathrm{H}_{2} \mathrm{O}$.

These results indicate that the citric acid acted as a carbon source to synthesize the $\mathrm{BaCO}_{3}$ during the burnout process; this generated barium carbonate was stable in a hydrogen atmosphere at $1073 \mathrm{~K}$. It is known that barium carbonate can be decomposed above $1273 \mathrm{~K}^{13)}$ Without citric acid, the barium precursor solution formed hydrated barium hydroxide, of which the boiling point was about $1050 \mathrm{~K}$; therefore, the powder in the alumina crucible was found to be completely molten in the humidified hydrogen atmosphere at $1073 \mathrm{~K}$. Because $\mathrm{Ba}(\mathrm{OH})_{2} \cdot \mathrm{H}_{2} \mathrm{O}$ should be dehydrated during heating, it will take the form of $\mathrm{Ba}(\mathrm{OH})_{2}$ at the fuel cell operating temperature of $1073 \mathrm{~K}$.

Figure 2 provides the $V-i$ polarization curves and the power densities of the fuel cells with $\mathrm{BaCO}_{3}(\mathbf{m})$ or $\mathrm{Ba}(\mathrm{OH})_{2}$ (A) as the catalysts (a) at the initial time and (b) after $5 \mathrm{~h}$. Initially, the performances of the fuel cells with different catalysts were nearly the same, and the peak power densities of the fuel cells with $\mathrm{BaCO}_{3}$ or $\mathrm{Ba}(\mathrm{OH})_{2}$ were $0.73 \mathrm{~W} \mathrm{~cm}$ and $0.69 \mathrm{~W} \mathrm{~cm}^{-2}$, respectively; however, as shown in Fig. 2(b),
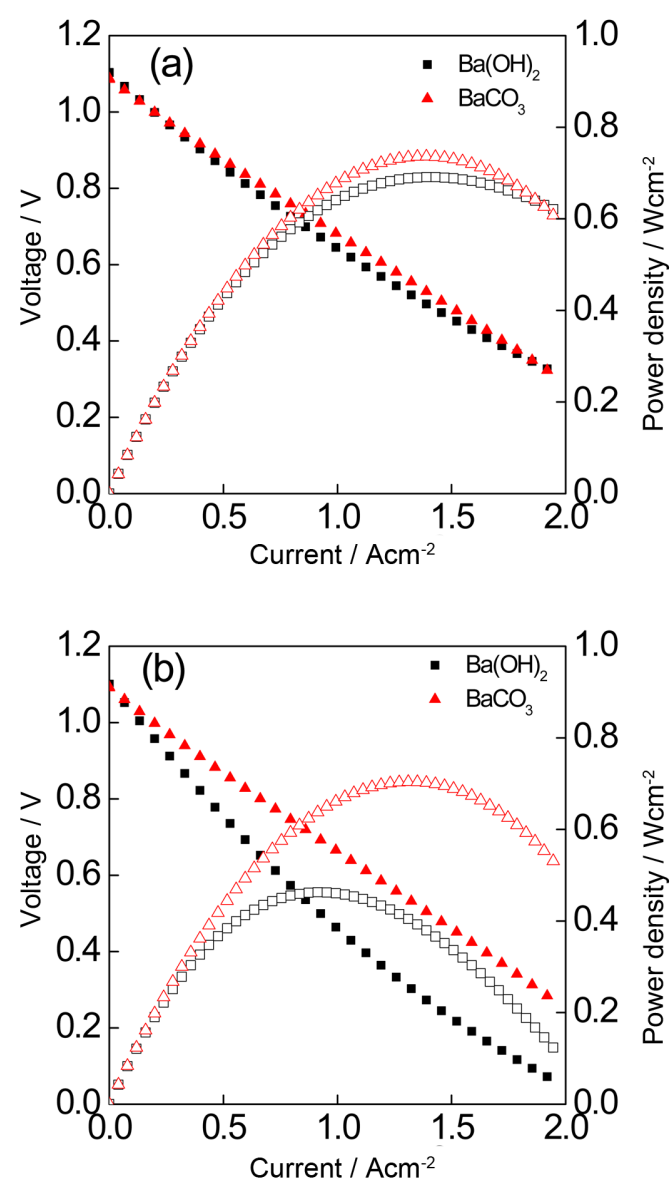

Fig. 2. $V$ - $i$ polarization curves and power densities of fuel cells with $\mathrm{BaCO}_{3}(\mathbf{\square})$ or $\mathrm{Ba}(\mathrm{OH})_{2}(\boldsymbol{\Delta})$ as the catalysts (a) at the initial time and (b) after $5 \mathrm{~h}$. after $5 \mathrm{~h}$, the peak power density of the fuel cells with $\mathrm{Ba}(\mathrm{OH})_{2}$ steeply decreased from $0.69 \mathrm{~W} \mathrm{~cm}^{-2}$ to $0.55 \mathrm{~W} \mathrm{~cm}^{-2}$, while that of the fuel cells with $\mathrm{BaCO}_{3}$ did not significantly change.

To distinguish the anode contribution to the fuel cell performances from the cathode contribution, a half-cell test of the LSF symmetric cell was performed. Fig. 3 shows a Nyquist plot of the AC impedance data from LSF symmetric cells measured at $1073 \mathrm{~K}$ in humidified air. Considering that the electrode of the cell was symmetric, both the real and imaginary impedances were divided by two, and the ohmic resistance was subtracted from the resulting value. As shown in Fig. 3, two arcs were identified at high frequency (summit frequency $=1 \mathrm{kHz}$ ) and at low frequency (below $0.1 \mathrm{kHz}$ ); the arc at the low frequency was much smaller than that at the high frequency. Generally, it is considered that an impedance arc of around $1 \mathrm{kHz}$ is associated with a surface reaction on the electrode, such as oxygen adsorption and dissociation. ${ }^{14)}$ Therefore, below $0.1 \mathrm{kHz}$, the contribution of the cathode became negligible.

Figure 4 shows the imaginary impedances (Im-Z) of the fuel cells with $\mathrm{BaCO}_{3}(\boldsymbol{\square})$ or $\mathrm{Ba}(\mathrm{OH})_{2}(\boldsymbol{\Delta})$ as catalysts at the

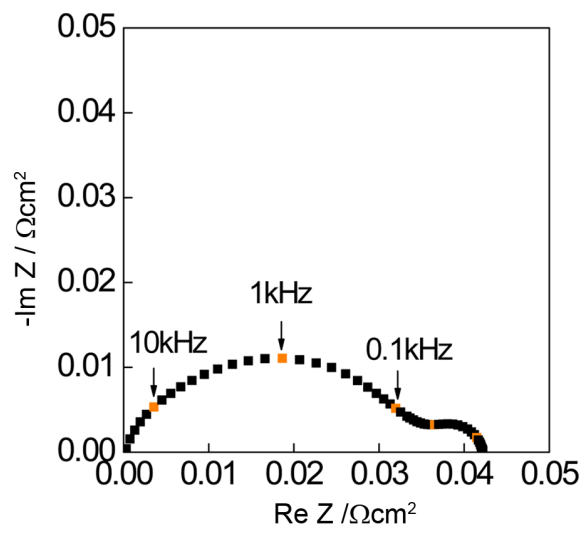

Fig. 3. Nyquist plot of the AC impedance data from the LSF symmetric cells measured at $1073 \mathrm{~K}$ in humidified air.

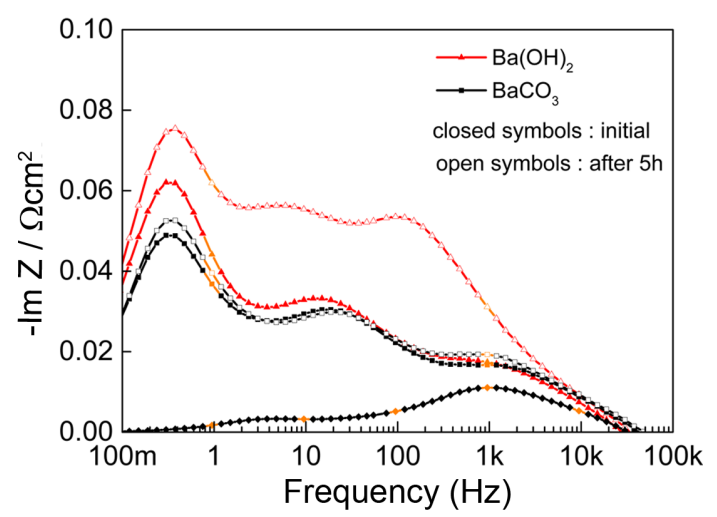

Fig. 4. Imaginary impedances (Im-Z) of the fuel cells with $\mathrm{BaCO}_{3}(\mathbf{\square})$ or $\mathrm{Ba}(\mathrm{OH})_{2}(\boldsymbol{\Delta})$ for the catalysts at the initial time (closed symbols) and after $5 \mathrm{~h}$ (open symbols), along with the Im-Z of the LSF symmetric cell. 
initial time (closed symbols) and after $5 \mathrm{~h}$ (open symbols), along with the Im-Z of the LSF symmetric cell. Below $1 \mathrm{kHz}$, the magnitude of the Im-Z of the LSF symmetric cell was much smaller than the magnitude of the Im- $Z$ of the fuel cells, which means that the $\mathrm{lm}-\mathrm{Z}$ below $1 \mathrm{kHz}$ was mainly caused by the anode rather than the cathode. The Im- $Z$ of the fuel cells showed three summits at the high, mid, and low frequencies, while the Im-Z of the LSF symmetric cell showed a single summit at a high frequency of around $1 \mathrm{kHz}$. Therefore, the summits of the Im- $\mathrm{Z}$ of the fuel cells found at the mid and low frequencies can be considered to be related to the anode.

In the case of the fuel cells with $\mathrm{BaCO}_{3}$, the Im- $\mathrm{Z}$ at the initial time was nearly the same as it was after $5 \mathrm{~h}$. The Im$\mathrm{Z}$ of the fuel cell with $\mathrm{Ba}(\mathrm{OH})_{2}$ at the initial time was also similar to that of the fuel cell with $\mathrm{BaCO}_{3}$; however, after 5 $\mathrm{h}$, the Im- $\mathrm{Z}$ of the fuel cell with $\mathrm{Ba}(\mathrm{OH})_{2}$ increased in the frequency range below $1 \mathrm{kHZ}$; one more summit was generated at about $110 \mathrm{~Hz}$. This change clearly shows that the catalytic activity of the anode with $\mathrm{Ba}(\mathrm{OH})_{2}$ significantly decreased with time.

The abrupt degradation of the performance of the fuel cell with $\mathrm{Ba}(\mathrm{OH})_{2}$ can be correlated with the low melting temperature of barium hydrate. The melting temperatures of monohydrated barium hydroxide and anhydrous barium hydroxide are $573 \mathrm{~K}$ and $680 \mathrm{~K}$, respectively. Such low melting temperatures can result in the loss of $\mathrm{Ba}(\mathrm{OH})_{2}$ at the high temperature of $1073 \mathrm{~K}$. Therefore, it can be said that the addition of citric acid to the barium precursor solution forms barium carbonate rather than barium hydroxide during ignition; this contributes to improving the long-term stability of the catalytic activity.

Figure 5 shows the (a) $V$-i polarization curves and the (b) Nyquist plots of the impedance spectra of the fuel cells i) without catalyst and with ii) $\mathrm{CeO}_{2}$ or iii) $\mathrm{BaCO}_{3}$ as catalysts at $1073 \mathrm{~K}$. As shown in Fig. 5(a), the slope of the $V$ - $i$ polarization curve became smaller with the addition of the catalysts; the addition of $\mathrm{BaCO}_{3}$ was slightly more effective at reducing the slope of the $V-i$ polarization curve than was the addition of $\mathrm{CeO}_{2}$. The peak power densities of the fuel cells without catalysts and with $\mathrm{CeO}_{2}$ or $\mathrm{BaCO}_{3}$ were $0.55 \mathrm{Wcm}^{-2}$, $0.66 \mathrm{Wcm}^{-2}$, and $0.74 \mathrm{Wcm}^{-2}$, respectively.

Fig. 5(b) shows the impedance spectra for a comparison of the electrode performances of these three types of cells. The cross section points on the real part of the impedance at high frequency and low frequency correspond to the ohmic area specific resistance (ASR) and the total ASR, respectively. The difference between the ohmic ASR and the total ASR is equal to the non-ohmic ASR, which represents the electrode performance. As shown in Fig.5(b), among the three cells, the total ASR of the fuel cell without a catalyst was largest; the fuel cell with $\mathrm{BaCO}_{3}$ had a smaller total ASR than that of the fuel cell with $\mathrm{CeO}_{2}$. Due to the similar thicknesses of the electrolytes, the ohmic ASRs of the three types of fuel cells were nearly the same. Therefore, Fig. 5(b) shows that the difference in the total ASRs was mainly due
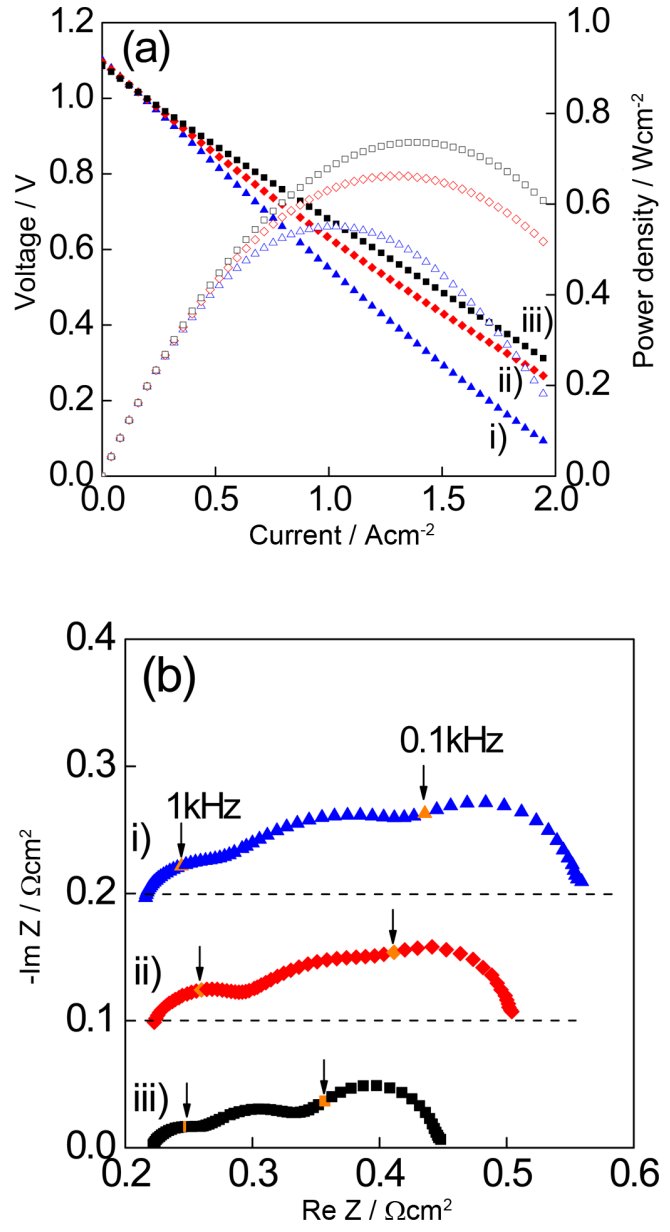

Fig. 5. (a) $V-i$ polarization curves and (b) Nyquist plots of impedance spectra of the fuel cells i) without catalyst and with ii) $\mathrm{CeO}_{2}$ or iii) $\mathrm{BaCO}_{3}$ as catalysts at $1073 \mathrm{~K}$.

to the difference in the electrode performance of the three types of cells.

To analyze the impedance data as a function of frequency, the impedance data shown in Fig. 5(b) are presented in a Bode-plot as a function of frequency in Fig. 6. Fig. 6 shows the Bode-plot of (a) the imaginary part and (b) the real part of the AC impedances of the fuel cells i) without catalyst and with ii) $\mathrm{CeO}_{2}$ or iii) $\mathrm{BaCO}_{3}$ as catalysts at $1073 \mathrm{~K}$. As shown in Figs. 6 (a) and (b), the characteristics of the impedance as a function of frequency were revealed more clearly in the imaginary part of the impedance data than in the real part.

In Fig. 6(a), three summits can be identified in the imaginary impedance data. For the three fuel cells, the heights of the summits at a high frequency of around $1 \mathrm{kHz}$ were similar. The impedance in this high frequency region is mainly attributed to the dissociative adsorption of oxygen in the cathode as well as to charge transfer at the interface between the electrode and the electrolyte in the anode. ${ }^{14)}$ These electrochemical reactions are affected by the LSF and the LSCM rather than by the catalysts dispersed on the 

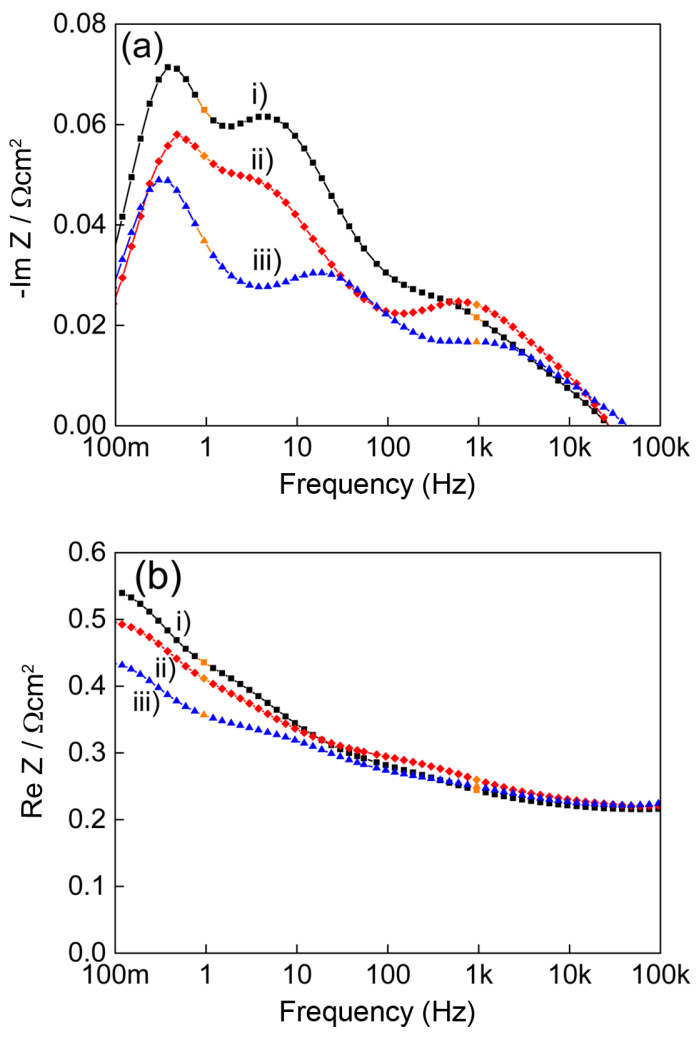

Fig. 6. Bode-plot of (a) the imaginary part and (b) the real part of the AC impedances of the fuel cells i) without catalyst and with ii) $\mathrm{CeO}_{2}$ or iii) $\mathrm{BaCO}_{3}$ as catalysts at $1073 \mathrm{~K}$.

LSCM, which results in similar levels of impedance at high frequencies above $1 \mathrm{kHz}$.

There were significant differences in the values of Im-Z among the three types of fuel cells in the frequency range below $1 \mathrm{kHz}$. Generally, it is known that the impedance data of the Ni-YSZ anode in low frequency regions should be attributed to gas diffusion and gas conversion; ${ }^{14-16)}$ however, the gas transport process could not have caused the difference shown in Fig. 6(a) because the same anode scaffold was used in all three types of cells.

Another possible reason for the impedance in the low frequency range is the slow kinetic chemical exchange reaction on the surface of the mixed ionic and electronic conductor. The slow surface reaction of the gas species can increase the impedance in the low frequency range, even when the reactant gas is abundant on the electrode surface. ${ }^{17)}$ This phenomenon has frequently been observed in ceramic electrode composite electrodes with poor catalytic activity. ${ }^{18)}$ Therefore, the reduction of the imaginary impedance of the fuel cell with $\mathrm{BaCO}_{3}$ in the low frequency range below $1 \mathrm{kHz}$ suggests that the addition of $\mathrm{BaCO}_{3}$ to the LSCM-YSZ composite anode enhanced the surface chemical exchange reaction. Interestingly, the promotion effect of $\mathrm{BaCO}_{3}$ was larger than that of $\mathrm{CeO}_{2}$, which has been widely used in anodes as a catalyst.

The reason that $\mathrm{BaCO}_{3}$ can improve the catalytic activity of the anode is still ambiguous. There are several possible candidates for this mechanism: the high catalytic activity of $\mathrm{BaCO}_{3}$, the substitution of Ba into LSCM, and the generation of catalytically active secondary phases. The exact mechanism and the application of $\mathrm{BaCO}_{3}$ as a catalyst will be studied in future work.

\section{Conclusions}

A barium precursor solution was infiltrated into an LSCM-YSZ ceramic composite anode to investigate the possible use of barium compounds as catalysts. The existence of citric acid in the barium precursor solution played a very important role in determining the phase of the barium compound in the fuel cell operating conditions. In a humidified hydrogen atmosphere at $1073 \mathrm{~K}$, a barium precursor solution with citric acid led to the formation of $\mathrm{BaCO}_{3}$, while the solution without a citric acid let to the formation of $\mathrm{Ba}(\mathrm{OH})_{2}$.

The fuel cell with $\mathrm{Ba}(\mathrm{OH})_{2}$ showed an initial good performance but this performance became significantly worse with time; the performance of the fuel cell with $\mathrm{BaCO}_{3}$ was stable and even higher than that of the fuel cell with $\mathrm{CeO}_{2}$ ceramic catalyst. Therefore, the addition of a small amount of barium precursor solution with citric acid to LSCM-YSZ can improve the performance of the LSCM-YSZ ceramic composite anode more than can the addition of the $\mathrm{CeO}_{2}$ catalyst.

\section{Acknowledgments}

This work was supported by the 2015 Research Fund of Myongji University.

\section{REFERENCES}

1. A. J. Jacobson, "Materials for Solid Oxide Fuel Cells," Chem. Mater, 22 [3] 660-74 (2010).

2. P. I. Cowin, C. T. G. Petit, R. Lan, J. T. S. Irvine, and S. Tao, "Recent Progress in the Development of Anode Materials for Solid Oxide Fuel Cells," Advanced Energy Materials, 1 [3] 314-32 (2011).

3. C. W. Sun, R. Hui, and J. Roller, "Cathode Materials for Solid Oxide Fuel Cells: A Review,” J. Solid State Electr., 14 [7] 1125-44 (2010).

4. S. Lee, N. Miller, and K. Gerdes, "Long-term Stability of SOFC Composite Cathode Activated by Electrocatalyst Infiltration," J. Electrochem. Soc., 159 [7] F301-8 (2012).

5. R. J. Gorte, S. Park, J. M. Vohs, and C. Wang, "Anodes for Direct Oxidation of Dry Hydrocarbons in a Solid-oxide Fuel Cell," Adv. Mater., 12 [19] 1465-69 (2000).

6. G. Kim, S. Lee, J. Y. Shin, G. Corre, J. T. S. Irvine, J. M. Vohs, and R. J. Gorte, "Investigation of the Structural and Catalytic Requirements for High-performance SOFC Anodes Formed by Infiltration of LSCM," Electrochem. Solid-State Lett., 12 [3] B48-52 (2009).

7. J.-S. Park, I. D. Hasson, M. D. Gross, C. Chen, J. M. Vohs, and R. J. Gorte, "A High-performance Solid Oxide Fuel Cell 
Anode Based on Lanthanum Strontium Vanadate," J. Power Sources, 196 [18] 7488-94 (2011).

8. S. Tao and J. T. S. Irvine, "Synthesis and Characterization of $\left(\mathrm{La}_{0.75} \mathrm{Sr}_{0.25}\right) \mathrm{Cr}_{0.5} \mathrm{Mn}_{0.5} \mathrm{O}_{3-\delta}$, a Redox-stable, Efficient Perovskite Anode for SOFCs," J. Electrochem. Soc., 151 [2] A252-59 (2004).

9. R. J. Gorte and J. M. Vohs, "Nanostructured Anodes for Solid Oxide Fuel Cells," Curr. Opin. Colloid Interface Sci., 14 [4] 236-44 (2009).

10. L. Yang, Y. Choi, W. Qin, H. Chen, K. Blinn, M. Liu, P. Liu, J. Bai, T. A. Tyson, and M. Liu, "Promotion of Water-mediated Carbon Removal by Nanostructured Barium Oxide/ Nickel Interfaces in Solid Oxide Fuel Cells," Nat. Commun., 2357 (2011).

11. M. Asamoto, S. Miyake, K. Sugihara, and H. Yahiro, "Improvement of Ni/SDC Anode by Alkaline Earth Metal Oxide Addition for Direct Methane-solid Oxide Fuel Cells," Electrochem. Commun., 11 [7] 1508-11 (2009).

12. T. Hong, F. Chen, and C. Xia, "Barium Carbonate Nanoparticle as High Temperature Oxygen Reduction Catalyst for Solid Oxide Fuel Cell," Electrochem. Commun., 51 93-97 (2015).
13. I. Arvanitidis, D. Siche, and S. Seetharaman, "A Study of the Thermal Decomposition of $\mathrm{BaCO}_{3}$, , Metall. Materi. Trans. B, 27 [3] 409-16 (1996).

14. R. Barfod, M. Mogensen, T. Klemensø, A. Hagen, Y.-L. Liu, and P. Vang Hendriksen, "Detailed Characterization of Anode-supported SOFCs by Impedance Spectroscopy," J. Electrochem. Soc., 154 [4] B371-78 (2007).

15. S. Primdahl and M. Mogensen, "Gas Conversion Impedance: A Test Geometry Effect in Characterization of Solid Oxide Fuel Cell Anodes," J. Electrochem. Soc., 145 [7] 2431-38 (1998).

16. S. Primdahl and M. Mogensen, "Gas Diffusion Impedance in Characterization of Solid Oxide Fuel Cell Anodes," J. Electrochem. Soc., 146 [8] 2827-33 (1999).

17. S. B. Adler, "Limitations of Charge-transfer Models for Mixed-conducting Oxygen Electrodes," Solid State Ionics, 135 [1-4] 603-12 (2000).

18. S.-E. Yoon, S.-H. Song, J. Choi, J.-Y. Ahn, B.-K. Kim, and J.-S. Park, "Coelectrolysis of Steam and $\mathrm{CO}_{2}$ in a Solid Oxide Electrolysis Cell with Ceramic Composite Electrodes," Int. J. Hydrogen Energy, 39 [11] 5497-504 (2014). 